\title{
Aplikasi Smartphone GIS (Geografik Information System) Pencarian Lapangan Futsal Daerah Tangerang Berbasis Android
}

\author{
Munich Heindari Ekasari ${ }^{1}$, Dessy Diana ${ }^{2}$, Mohamad Saefudin ${ }^{3}$ \\ Sistem Informasi, STMIK Jakarta STI\&K \\ Email: ${ }^{1}$ munich.heindari@gmail.com, ${ }^{2}$ desidiana2208@gmail.com, ${ }^{3}$ saefudin@gmail.com \\ Submitted Date: January $13^{\text {th }}, 2020$ \\ Reviewed Date: January $14^{\text {th }}, 2020$ \\ Revised Date: January $28^{\text {th }}, 2020$ \\ Accepted Date: January $31^{\text {st }}, 2020$
}

\begin{abstract}
Geographyc Information System (GIS) is an information system that is applied to store, recall, enter, analyze, process, and produce data in the form of geographic data, used for decision making in support of a system development plan. The problem of finding information to find out the location of various places in an area with the help of smart phones. The use of smart phones in a growing community, then the idea arose to create an application called Find Your Futsal, which is an application about futsal field information based on the Geographyc Information System in the Tangerang area. Futsal has many benefits for the surrounding community. They can use the futsal field to support various futsal activities. The design method of this GIS application research application uses the SDLC (System Development Life Cycle) research method. Started designing the displays in the application, designing the database used in making the application. Next start the application by coding with a predetermined programming language using the Android Studio application. Furthermore, it is compiled and implemented on Android-based mobile devices. The application of the results of this study is a geographic information system application futsal field in the city of Tangerang that is simple and easy to use. As well as GPS and maps as features in it.
\end{abstract}

Keywords: GIS, Futsal, Tangerang, Android, smart phone

\begin{abstract}
Abstrak
Geographyc Information System (GIS) merupakan sistem informasi yang diterapkan untuk menyimpan, memanggil kembali, memasukkan, menganalisa, mengolah, dan menghasilkan data berupa data geografis, digunakan untuk pengambilan keputusan dalam mendukung suatu perencanaan pembuatan sistem. Masalah pencarian informasi untuk mengetahui lokasi berbagai tempat pada disuatu wilayah demgan bantuan ponsel pintar. Penggunaan ponsel pintar di masyarakat semakin berkembang, maka timbul ide untuk membuat sebuah aplikasi bernama Find Your Futsal, yaitu aplikasi mengenai informasi lapangan futsal berbasis Geographyc Information System yang ada di wilayah Tangerang. Futsal sangat mempunyai banyak manfaat bagi masyarakat sekitar. Mereka dapat menggunakan lapangan futsal untuk menunjang berbagai kegiatan futsal. Metode perancangan aplikasi penelitian aplikasi GIS ini menggunakan metode penelitian SDLC (System Development Life Cycle). Dimulai merancang tampilan-tampilan yang ada di aplikasi tersebut, merancang database yang digunakan dalam pembuatan aplikasi. Selanjutnya memulai pembuatan aplikasi dengan pengkodean dengan bahasa pemrograman yang sudah ditentukan yaitu menggunakan aplikasi android studio. Selanjutnya dilakukan kompilasi dan diimplementasikan pada perangkat ponsel berbasis Android. Penerapan hasil penelitian ini adalah sebuah aplikasi informasi system geografis lapangan futsal di Kota Tangerang yang sederhana dan mudah digunakan. Serta GPS dan maps sebagai fitur-fitur yang ada di dalamnya.
\end{abstract}

Kata kunci: GIS, Futsal, Tangerang, Android, ponsel pintar

\section{Pendahuluan}

Perangkat bergerak yang perkembangannya pesat saat ini berbasis Android. Android merupakan sistem operasi yang digunakan telpon selular berbasis Linux. Android juga menyediakan platform terbuka bagi para pengembang untuk menciptakan aplikasi sendiri. Ada beberapa keunggulan yang dimiliki oleh Android, di 
antaranya adalah Open source, ketersediaan aplikasi yang berkualitas, keberagaman pilihan perangkat, harga terjagkau, bebas mengatur ukuran ROM, dan terkoneksi dengan seluruh layanan Google, seperti Gmail, Google Docs, Google Maps, YouTube, Google Talk, Google+, dan mesin pencari Google. Peneliti mengangkat tema Android sebagai bahan penelitian. Penelitian ilmiah ini peneliti membangun sebuah aplikasi yang berisikan tentang informasi lapangan Futsal di daerah Tangerang. Futsal adalah olahraga yang sangat popular sehingga olahraga ini banyak digemari masyarakat dari berbagai golongan khususnya masyarakat di daerah Tangerang.

Penyaluran hobi futsal banyak dibangun tempat-tempat untuk menyediakan sarana dan prasarana pendukung untuk melakukan olahraga futsal di daerah Tangerang. Aplikasi ini berbasis Geographic Information System atau lebih dikenal dengan GIS sehingga dapat menuntun para pemakai aplikasi untuk tahu di mana lokasi lapangan futsal. Aplikasi ini dibuat dengan menggunakan bahasa pemrograman java dalam Android Studio. Keunggulan bahasa pemrograman java adalah multiplatform, pemrograman berbasis objek, perpustakaan kelas yang lengkap dan memiliki fasilitas pengaturan penggunaan memori. Sedangkan kelebihan mobile Android adalah multitasking, kemudahan dalam notifikasi dan akses mudah terhadap ribuan aplikasi Android.

Adapun batasan masalah dari penelitian ini adalah konsep dari GIS (Geographic Information System) sebagai penyedia dan pemroses informasi berdasarkan lokasi mengenai informasi geografis yang berkaitan dengan lapangan futsal yang ada di Kota Tangerang. Informasi yang adaantara lain: alamat, nomor telepon dan peta. Aplikasi ini menerapkan fitur GPS dalam perangkat Android. Aplikasi ini terdapat 19 lapangan futsal di Kota Tangerang. Aplikasi ini menggunakan bahasa pemrograman java \& XML sebagai bahasa pemrogramannya.

Penelitian ini bertujuan untuk membangun sebuah aplikasi informasi system geografis lapangan futsal di Tangerang yang sederhana, mudah dibawa dan diharapkan dapat membantu para pemakai. System informasi geografis (Geographic Information System) yang terdapat di dalam aplikasi ini, pemakai dapat dengan mudah mengetahui lokasi lapangan futsal yang ada di daerah Tangerang. GIS adalah sistem yang digunakan untuk menangkap, menyimpan, menganalisa, serta mengelola data dan karakteristik yang berhubungan secara special mengambil referensi ke bumi. Sistem ini dapat didefinisikan sebagai system computer untuk memadukan, menyimpan, membagi, serta menampilkan informasi yang mengambil acuan geografis.

\section{Pustaka Terkait}

\subsection{Futsal}

Futsal adalah salah satu cabang olahraga yang termasuk dalam permainan bola besar. Futsal, dewasa ini berkembang menjadi salah satu permainan alternatif sepak bola, menilik pada efisiensi pernggunaan lahan atau lapangan bermain yang lebih kecil. Oleh karenaitu futsal dianggap sebagi permainan yang mampumemberikan sensasi bermain yang sama halnya yang didapat oleh pemain saat bermain sepak bola (Achwani, Muhammad. 2016)

\subsection{Android}

Android merupakan suatu sistem operasi berbasis Linux dipergunakan untuk telepon seluler seperti telepon pintar atau komputer tablet. Android adalah aplikasi platform terbuka utuk para pengembang dalam menciptakan aplikasi mereka dan digunakan dengan bermacam peranti bergerak. Awalnya, Google Inc. membeli Android Inc. pendatang baru yang membuat peranti lunak untuk ponsel. Perkembangan Aplikasi Android lebih lanjut maka dibentuklah Open Handset Alliance, yaoitu suatu konsorsium terdiri dari tiga puluh empat perusahaan hardware, software, dan telekomunikasi, termasuk didalamnya adalah Google, HTC, Qualcomm, Motorola, T-Mobile, Intel, dan Nvidia.

Dewasa ini terdapat dua jenis distributor besar sistem operasi Android. Pertama yang mendapat dukungan penuh dari Google atau Google Mail Services (GMS) dan keduaadalah yang benar-benar bebas distribusinya tanpa dukungan langsung Google atau dikenal sebagai Open Handset Distribution (OHD) (N. Safaat, 2015)

\subsection{Android Studio}

Android Studio merupakan perangkat lunak terintergrasi berupa Lingkungan Pengembangan Terpadu - Integrated Development Environment (IDE) dalam pengembangan aplikasi Android, berdasarkan IntelliJ IDEA . Android Studio merupakan editor kode IntelliJ juga alat pengembang yang banyak manfaatnya. Android Studio juga menawarkan fitur sangat banyak untuk meningkatkan produktivitas para pengembang 
membuat aplikasi Android, (N. Safaat, 2015) misalnya:

- Sistem versi berbasis Gradle yang fleksibel

- Emulator yang cepat dan kaya fitur

- Lingkungan yang menyatu untuk pengembangan bagi semua perangkat Android

- Instant Run digunakan untuk membuat aplikasi yang berjalan tanpa membuat APK baru

- Template kode yang terintegrasi dengan GitHub sebagai fitur aplikasi yang sama dan mengimpor kode contoh

- Alat pengujian dan kerangka kerja yang ekstensif

- Alat Lint untuk meningkatkan kinerja, kegunaan, kompatibilitas versi, dan masalahmasalah lain

- Dukungan $\mathrm{C}++$ dan NDK

- Dukungan bawaan untuk Google Cloud Platform, mempermudah pengintegrasian Google Cloud Messaging dan App Engine.

Selain berbagai keunggulan yang ada pada Android Studio, software ini juga memiliki kelemahan yaitu lebih berat digunakan dibandingkan dengan Eclipse IDE. Namun jika dilihat dari berbagai sudut pandang, Android Studio lebih unggul sebagai software pengembang aplikasi Android dan cepat dalam melakukan update ke versi terbarunya. Sistem Minimal yang dibutuhkan oleh android studio yaitu:

- OS Windows 7/8 32 - 64 bit

- RAM 3 GB Minimum , Disarankan memakai RAM 8 GB , I GB untuk Android Emulator

- 2 GB Minimum Ruang di Hardisk 4 GB Disarankan

- 1280 x 800 Minimum Resolusi Layar

- Java Development Kit (JDK) 7 or Java Development Kit ( JDK ) 8 (Support API 24 ,Android Nougat

- Untuk bisa mengakses emulator terbaru pastikan intel processor kalian mendukung Intel ${ }^{\circledR}$ VT-x, Intel ${ }^{\circledR}$ EM64T (Intel ${ }^{\circledR}$ 64), and Execute Disable (XD) Bit functionality.

\subsection{Google API}

Google API bisa di katakan bagian dari Framework Google. Google menyediakan fungsi API (Application Programming Interface) sangat berguna untuk pengembang jenis web atau aplikasi desktop. API ini memanfaatkan banyak fitur yang disediakan Google seperti misalnya: AdSense, Search Engine, Translation maupun YouTube. API bisa diartikan secara sederhana sebagai kode program yang menyediakan antarmuka atau penghubung antara aplikasi berbasis web dengan fungsi-fungsi yang mendukung.

Google API adalah kode program yang disederhanakan untuk kita tambahkan ke sebuah aplikasi atau web yang kita bangun. Kode API ini dapat dipergunakan untuk mengakses, menjalankan, memanfaatkan fungsi atau fitur yang ada pada Google. Misalnya saja kita bisa menambahkan fitur Google Map pada website kita. Google API dapat dipelajari langsung melalui Google Code. Pada fungsi Google Code kita belajar tentang Google API kemudian dapat mengimplementasikan pada aplikasi website yang kita kembangkan. Berikut ini adalah sebagian kode API yang terdapat pada Google, beberapa di antaranya adalah:

1. Language API: untuk memanfaatkan fitur translation yang dimiliki Google.

2. Earth API: memanfatkan fitur yang ada pada Google Earth

3. Javascript API

4. Maps API: memanfaatkan fitur yang ada pada Google Maps

5. Search API: memanfaatkan fitur pencarian pada Google Search

6. Visualization API berfungsi untuk membuat grafik atau chart dengan Google API

7. YouTube API digunakan untuk memanfaatkan fitur YouTube seperti untuk pencarian video

Salah satu manfaat mempelajari Google API adalah memanfaatkan Google AJAX APIs Playground. AJAX APIs playground merupakan sebuah alamat internet disediakan Google untuk kita mencoba secara langsung banyak Google API yang berbasis AJAX (Asynchronous Javascript and XML). Semua kode program dalam sintaks Javascript dapat di lihat dan dikopi paste secara langsung kemudian di digunakan website kita. Google AJAX API dapat kita integrasikan data pada website kita dengan memanfaatkan fitur API yang disediakan oleh Google. (Rena Ariyanti, Khairil, Indra Kanedi, 2015)

\subsection{SDK}

Android-SDK adalah perangkat bagi para pengembang aplikasi yang ingin membuat aplikasi berbasis google android. Android SDK di dalamnya terdapat seperangkat alat pengembangan sangat komprehensif. Android SDK terdiri dari libraries, debugger, handset emulator, dokumentasi, tutorial, dan contoh kode. Saat ini 
Android sudah mendukung arsitektur x86 pada Linux (distribusi Linux apapun untuk desktop modern), Mac OS X 10.4.8 atau lebih, Windows XP atau Vista. Persyaratanmencakup JDK, Apache Ant dan Python 2.2 atau yang lebihbaru. IDE yang didukung secara resmi adalah Android Studio, dengan ini pengembang dapat menggunakan teks editor untuk mengedit file Java dan XML serta menggunakan peralatan command line untuk menciptakan, membangun, melakukan debug aplikasi Android dan pengendalian perangkat Android (misalnya, reboot, menginstal paket perangkat lunak dengan jarak jauh) (M. Ichwan, Fifin Hakiky, 2011)

\subsection{Java Script}

JavaScript merupakanbahasa script popular dipakai untuk menciptakan halaman Web yang dapat berinteraksi dengan pengguna dan dapat merespon event yang terjadi pada halaman. Java Script merupakan perekat yang menyatukan halaman-halaman Web. Akan sangat susah menjumpai halaman Web komersial yang tidak memuat kode Java Script (Irawan, 2012)

\subsection{Map Type}

Google Maps ini layanan gratis yang diberikan oleh Google dan sangat popular. Google Maps berisi peta dunia dan dapat kita gunakan melihat suatu area dibumi. Aplikasi Google Maps adalah suatu peta dijalankan menggunkan aplikasi dalam bentuk browser. Kita bias menambahkan fitur Google Maps ke web yang kita kembangkan atau pada blog berbayar ataupun gratis sekalipun fitur Google Maps API. Google Maps API berbentuk library yang dibangun menggukan bahasa JavaScript.

Sedangkan, Map Type merupakan tipe peta yang ditampilkan, dimana peta di tampilkann dalam bentuk jalan ataupun secara penampakan dari atas satelit. Tipe peta yang saya gunakan adalah tipe peta Road, karena mungkin para pengunjung atau wisatawan membutuhkan peta untuk mencapai objek wisata tujuan mereka yang berupa gambar jalan.

\subsection{Adobe Photoshop}

Adobe Photoshop merupakan sebuah aplikasi pengolahgambar (digital imaging) yang banyak digunakan dan memberikan kontribusi besar bagidunia digital dancetak. Dalam perkembangannya software ini mengalami beberapa peningkatan versi. Pada versiter barunya, Adobe sebagai developer aplikasi mengeluarkan versi terbarunya,yaitu Adobe Photoshop CC atau Creative Cloud (Macdoms, 2009)

\subsection{Struktur Navigasi}

Struktur navigasi merupakan urutan alur informasi aplikasi multimedia. Struktur navigasi merupakan suatu aplikasi multimedia yang mempunyai suatu pedoman dan arah informasi yang jelas (Suyanto, Asep Herman, 2008).

\section{Metode Penelitian}

Untuk memperoleh bahan-bahan dan informasi yang dibutuhkan dalam perancangan aplikasi menggunakan metode penelitiab SDLC (System DevelopmentLife Cycle). Tahapan metode SDLC dibagi menjadi 5 bagian, yaitu: fase identifikasi, fase analis, fase perancangan, fase implementasi, dan fase uji coba.

Fase analisis, pada fase ini adalah memecahkan masalah dalam pembuatan aplikasi dan menggambar kerangka agar terlihat dengan jelas hal-hal yang perlu dilakukan dalam proses pembuatan aplikasi, mengumpulkan dan mempelajari berbagai sumber pustaka yang berhubungan dengan data dan android.

Fase perancangan, pada fase ini dimulai membuat, rancangan tampilan. Dalam merancang tampilan perlu dipikirkan aspek pendukung seperti design interface dan beberapa aspek lainnya sehingga pengguna dapat menikmati tampilan aplikasi analisa ini.

Fase implementasi dan uji coba akan dilakukan pada komputer dengan menggunakan laptop Acer Aspire 4740G dengan spesifikasi Processor Intel@ Core i5 M430 @2.26GHz, RAM 4 GB dan VGA GeForce 310M serta aplikasi Android Studio.

\section{Perancangan dan Implementasi}

Pada bab ini akan membahas perancangan yang digunakan pada aplikasiFind Your Futsal. Tahapan yang dilakukan untuk mendukung pembuatan aplikasi ini dengan membuat struktur navigasi, storyboard, perancangan interface, implementasi, spesifikasi software dan hardware.

Aplikasi ini dirancang untuk memberikan informasi kepada masyarakat serta lokasi lapangan futsal yang ada di wilayah kota Tangerang dengan bantuan google maps.

\subsection{Rancangan Aplikasi}

Perangcangan Aplikasi merupakan tahapan dari rancangan program yang akan dilakukan. Pertama adalah merancang diagram UML(Unified Modelling Language).Diagram UML yang akan 
dibuat adalah Use Case Diagram dan Activity Diagram.

\subsection{Use Case Diagram}

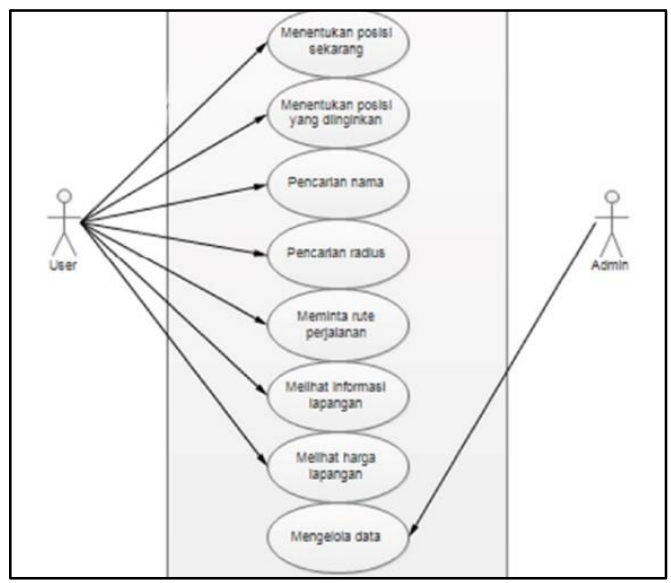

Gambar 1 Use Case Diagram

Berikut adalah penjelasan dari diagram Use Case di atas:

- Find merupakan suatu proses yang dilakukan user agar dapat mengetahui lapangan futsal yang berada di wilayah Tangerang.

- Pada saat user memilih menu Find , user dapat memilih daftar lapangan futsal yang sudah tersedia.

- Setelah user memilih lapangan futsal, lalu akan muncul tampilan informasi lapangan mengenai alamat lapangan, nomor telepon, jumlah lapangan, jenis lapangan, ukuran lapangan, jam operasional dan harga sewa lapangan.

- Kemudian saat user memilih cek lokasi makauser dapat mengetahui informasi lokasi lapangan futsal yang sudah dipilih pada menu sebelum dengan bantuan Google Maps.

- Lalu saat user memilih call maka user akan langsung menelpon ke nomor lapangan futsal yang sudah dipilih pada menu sebelumnya.

- Pada saat user memilih help untuk menampilkan cara penggunaan aplikasi tersebut.

- Lalu saat user memilih menu About untuk menampilkan tujuan dari aplikasi.

- Kemudian saat user memilih menu exit untuk keluar dari aplikasi.

\subsection{Activity Diagram}

Secara umum, activity diagram menggrambarkan alur aktivitas dalam sistem, bagaimana masing-masing alur berawal, decision yang mungkin terjadi, dan bagaimana mereka berakhir. State awal dari aplikasi ini adalah Splash Screen. Kemudian dilanjutkan ke Menu utama dan ditemukan oleh proses pararel, yaitu proses state memilih menu Find, memilih menu help, memilih menu about dan memilih menu exit.



Gambar 2 Activity Diagram

Pada kondisi pertama yaitu user memilih menu Find . Menu tersebut akanmasuk ke tampilan yang berisi daftar lapangan futsal yang dapat dipilih oleh user.Jika user telah memilih lapangan futsal yang diinginkan maka akan berpindah ke tampilan yang memberikan informasi tentang lapangan futsal yang sudah dipilih oleh user.Pada tampilan menu informasi lapangan futsal terdapat 2 tombol yang dapat membantu user untuk melihat navigasi dari tempat user berada ke lokasi lapangan futsal dengan menggunakan google maps dan untuk menelpon ke lapangan futsal yang sudah dipilih.

Pada kondisi kedua pada saat user memilih menu Help yang akan menjelaskan cara penggunaan aplikasi yang telah dibuat.

Pada kondisi ketiga yaitu user memilih menu About, pada menu ini menjelaskan tentang tujuan serta kegunaan dari aplikasi yang telah dibuat.

Pada kondisi keempat jika user memilih menu Exit akan muncul alert dialog yang terdapat dua pilihan yaitu jika user memilih ya maka akan keluar dari aplikasi, lalu jika user memilih tidak maka user akan tetap di menu utama. 


\subsection{Struktur Navigasi}

Rancangan struktur navigasi pada aplikasi GIS lapangan futsal di daerah Tangerang berbasis android ini menggunakan struktur navigasi hirarki atau yang sering disebut struktur navigasi bercabang. Struktur navigasi bercabang merupakan struktur yang mengandalkan percabangan untuk menampilkan data berdasarkan kriteria tertentu.

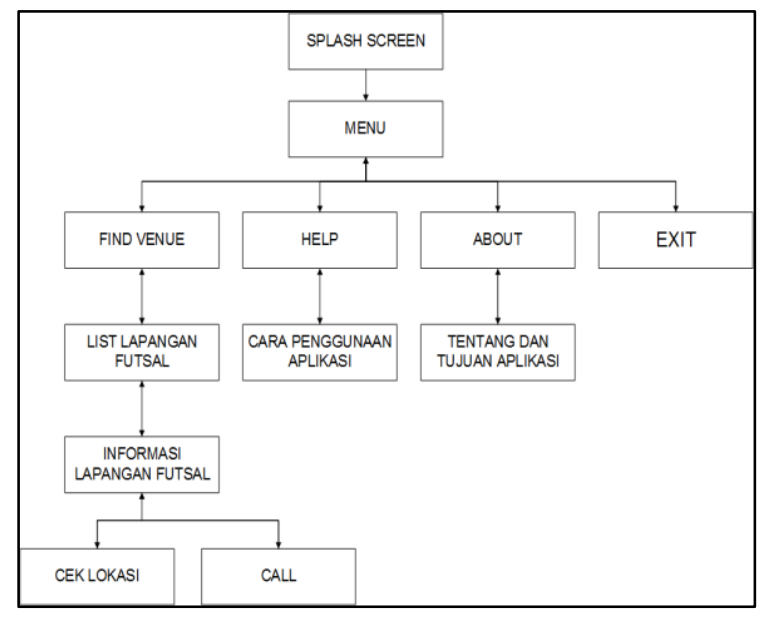

Gambar 3 Struktur Navigasi

Dari Struktur navigasi di atas, dapat dilihat tampilan menu utama terdiri dari 4 menu yaitu Find , Help, About, Exit. Menu Find berisikan list lapangan futsal yang ada di kota Tangerang. Selanjutnya jika sudah memilih lapangan futsal yang diinginkan, akan muncul halaman informasi lapangan futsal yang telah dipilih berserta gambarnya, lalu terdapat 2 tombol yaitu tombol cek lokasi untuk mengetahui lokasi lapangan dan tombol call untuk menelpon. Kemudian pada menu Help akan menampilkan cara menggunakan aplikasi. Lalu pada menu About akan memunculkan dialog tentang aplikasi. Dan menu Exit untuk keluar dari aplikasi.

\subsection{Storyboard}

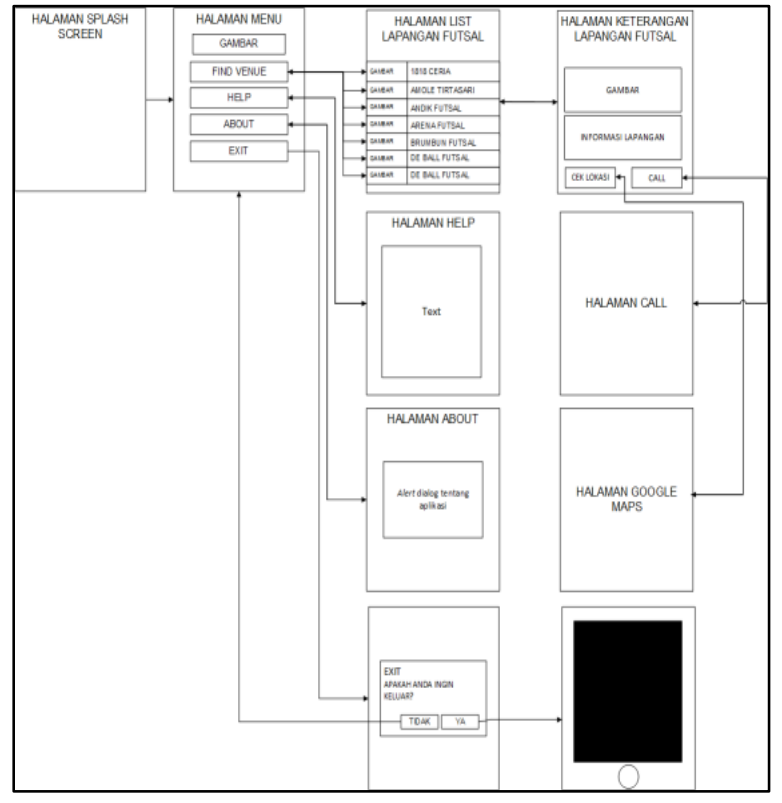

Gambar 4 Storyboard

Storyboard berisi sebuah gambar sketsa yang digunakan untuk perancangan aplikasi dan menunjukan secara visual bagaimana sebuah aplikasi berjalan. Dalam aplikasi storyboard menerangkasn tentang perjalanan user dalam menggunakan aplikasi ini. (Dhimas, Andreas, 2013). Gambar 4 adalah storyboard dari aplikasi Find Your Futsal.

\subsection{Rancangan Aplikasi}

Rancangan tampilan aplikasi yang dibuat akan memberikan gambaran serta penjelasan dari tiap gambar dan teks. Tampilan ini menggambarkan sebuah hubungan anatara tampilan yang satu dengan yang lainnya. Selain itu rancangan tampilan bertujuan supaya aplikasi yang dihasilkan menarik,mudah dipahami dan mudah penggunaannya.

\subsection{Rancangan Halaman Splash Screen}

Halaman Splash Screen adalah halaman awal yang ditampilkan oleh aplikasi ini, dimana halaman ini menampilkan gambar dan progressbar yang sudah diatur dalam hitungan detik untuk masuk ke halaman selanjutnya.

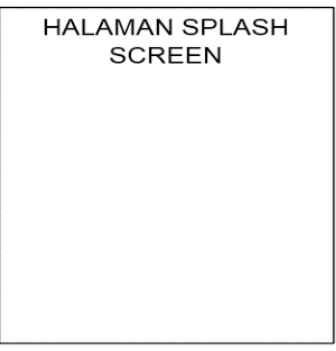


Gambar 5 Rancangan Splash Screen

\subsection{Rancangan Halaman Menu}

Secara umum pada aplikasi ini menampilkan 4 Menu utama dalam bentuk tombol, yaitu Find , Help, About, dan Exit. Rancangan tampilan Menu sebagai berikut:

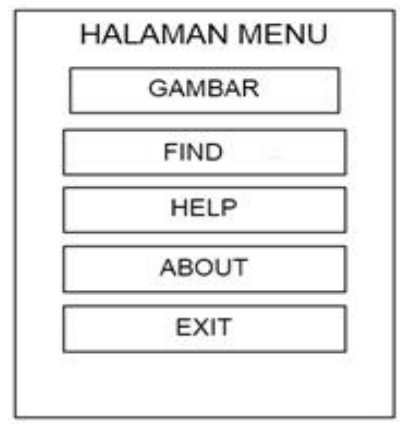

Gambar 6 Rancangan Menu

\subsection{Rancangan Halaman Find}

Rancangan ini menampilkan daftar lapangan futsal di wilayah Tangerang. User dapat memilih salah satu dari daftar lapangan futsal yang tersedia. User akan memilih salah satu lapangan futsal yang akan menampilkan gambar lapangan futsal dan memberikan informasi mengenai alamat, nomor telpon, jumlah lapangan, jenis lapangan, ukuran lapangan, jam operasional, harga sewa lapangan, tombol untuk menampilkan lokasi lapangan futsal dengan bantuan google maps dan tombol untuk melakukan panggilan ke lapangan futsal.

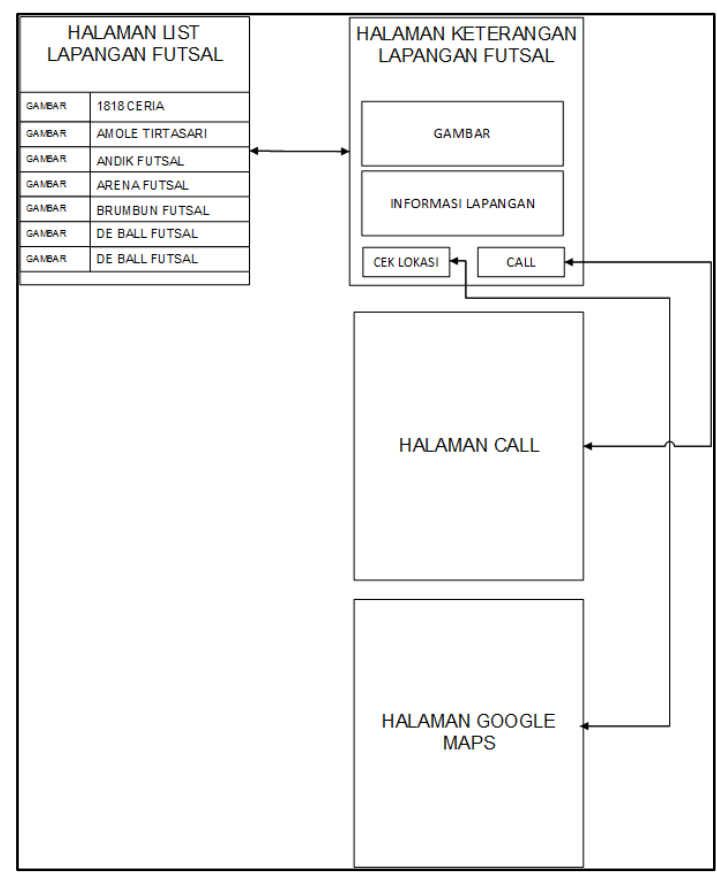

Gambar 7 Rancangan Halaman Find Futsal

\subsection{Rancangan Halaman Help}

Pada rancangan halaman menu Help, berisi informasi tentang cara penggunaan aplikasi ini. Halaman ini menggunakan TextView yang akan menampilkan isi pesan dari halaman.

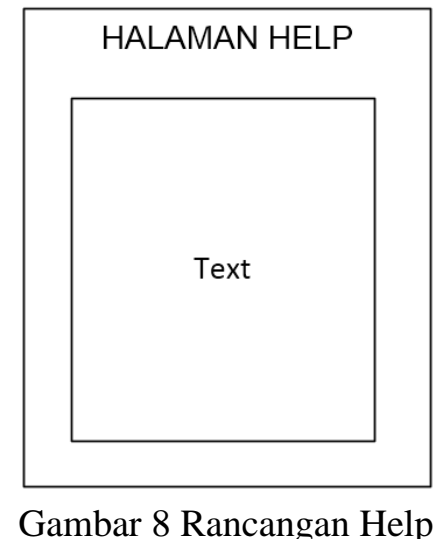

\subsection{Rancangan Halaman About}

Halaman ini merupakan sebuah tampilan pop up dialog yang menampilkan tujuan dan kegunaan dari aplikasi ini. Dibawah ini adalah rancangan tampilan halaman About.

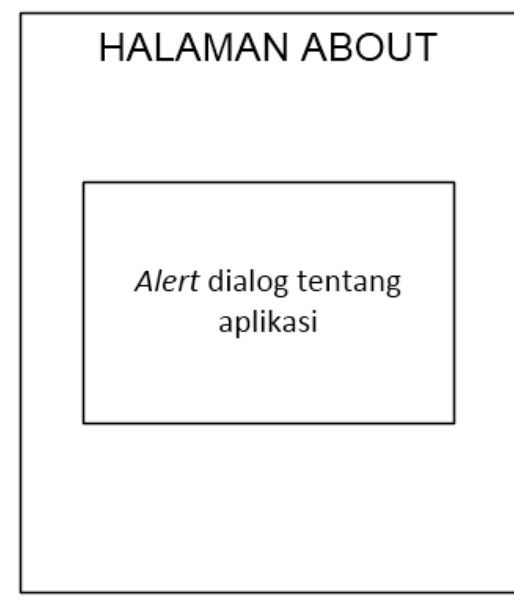

Gambar 9 Rancangan About

\subsection{Rancangan Halaman Exit}

Halaman Exit adalah halaman yang bertujuan untuk mengakhiri program aplikasi atau kembali untuk menggunakan aplikasi tersebut. Halaman ini memunculkan alertdialog dengan 2 pilihan ketika tombol Exit ditekan pada menu utama. Maka akan muncul pilihan yang pertama Ya untuk keluar dari aplikasi dan pilihan kedua Tidak untuk kembali menggunakan aplikasi. Berikut adalaha rancangan tampilan halaman keluar: 


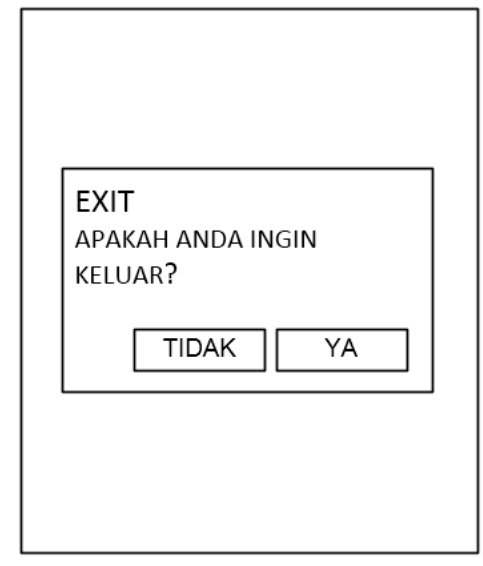

Gambar 10 Rancangan Exit

\section{Hasil Dan Pembahasan}

Setelah melalui tahap perancangan aplikasi, Selanjutnya masuk ke tahap implementasi. Pembuatan aplikasi ini memiliki beberapa bagian yaitu Menu utama yang berisi tombol Find , Help, About, dan Exit. Untuk membuat aplikasi ini pada android studio membuat desain tampilan dengan bentuk .xml yang berada pada folder resource (res). Untuk menjalankan programnya yang berbentuk .java dapat diketikkan beberapa kodingan sesuai kebutuhan.

\subsection{Halaman Splash Screen}

Tampilan di bawah ini merupakan tampilan halaman Splash Screen yang menjadi tampilan awal aplikasi ini.

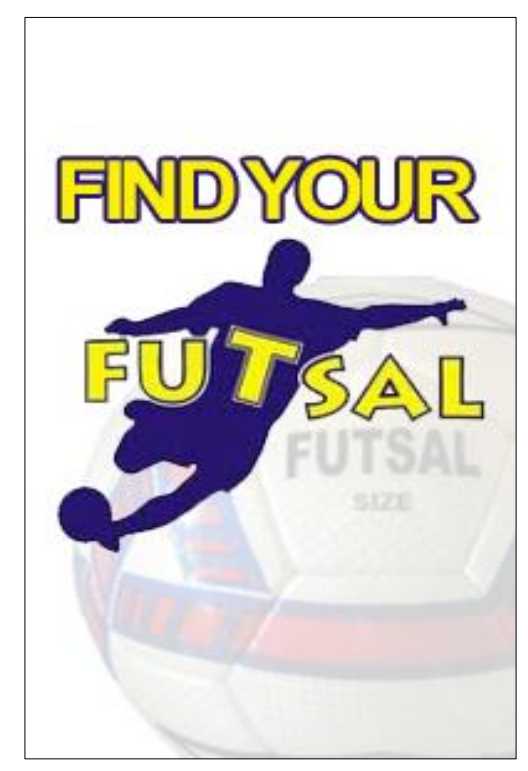

Gambar 11 Splash screen

\subsection{Halaman Menu}

Tampilan di bawah ini merupakan tampilan halaman menu utama yang berisi gambar serta empat tombol yaitu Find, help, about dan, exit.

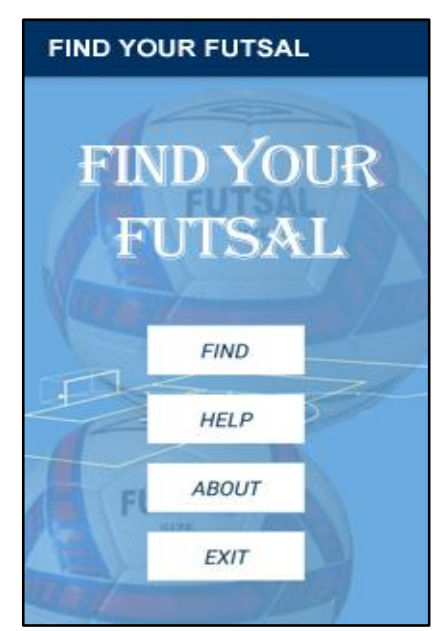

Gambar 12 Halaman Menu

\subsection{Halaman Daftar Lapangan Futsal}

Tampilan di bawah ini merupakan tampilan halaman daftar lapangan futsal yang berisi daftar lapangan futsal di wilayah Tangerang.

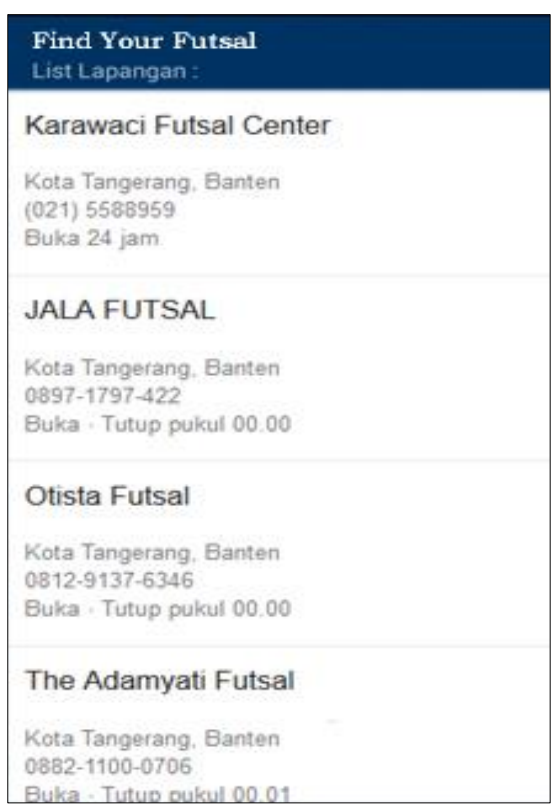

Gambar 13 Daftar Lapangan Futsal

\subsection{Halaman Informasi Futsal}

Tampilan di bawah ini merupakan tampilan halaman informasi lapangan futsal yang terdiri dari alamat, nomor telpon, jumlah lapangan, jenis lapangan, ukuran lapangan, jam operasional, harga sewa lapangan serta 2 tombol yaitu cek lokasi dan call. 


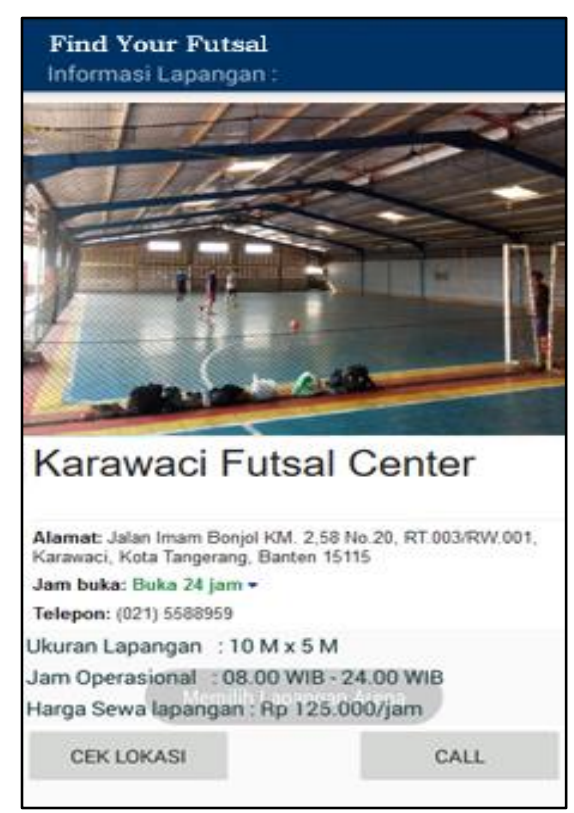

Gambar 14 Informasi Lapangan Futsal

Tampilan di bawah ini adalah tampilan maps dari button cek lokasi yang kordinat lokasi lapangan futsalnya sudah ditentukan pada marker.

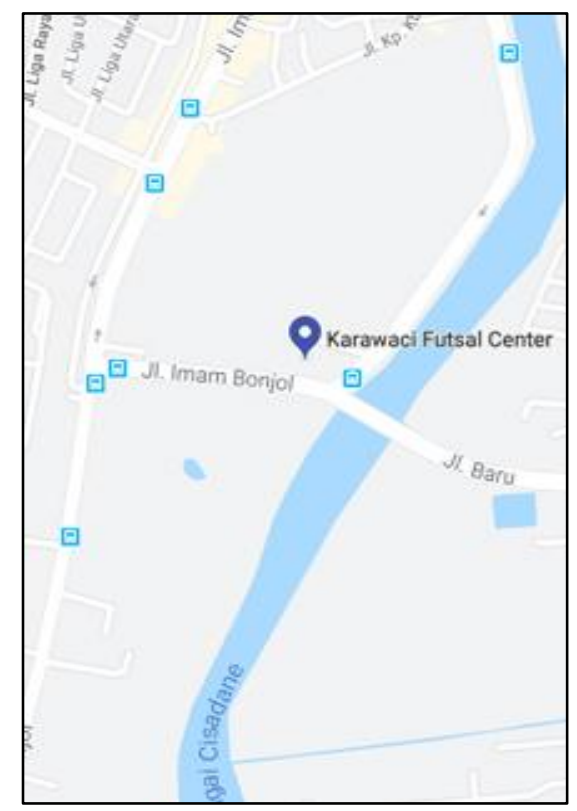

Gambar 15 Tampilan Maps

Jika pengguna menekan tombol call maka akan muncul tampilan dibawah ini yaitu tampilan saat melakukan panggilan ke nomor yang sudah ditentukan sebelumnya.

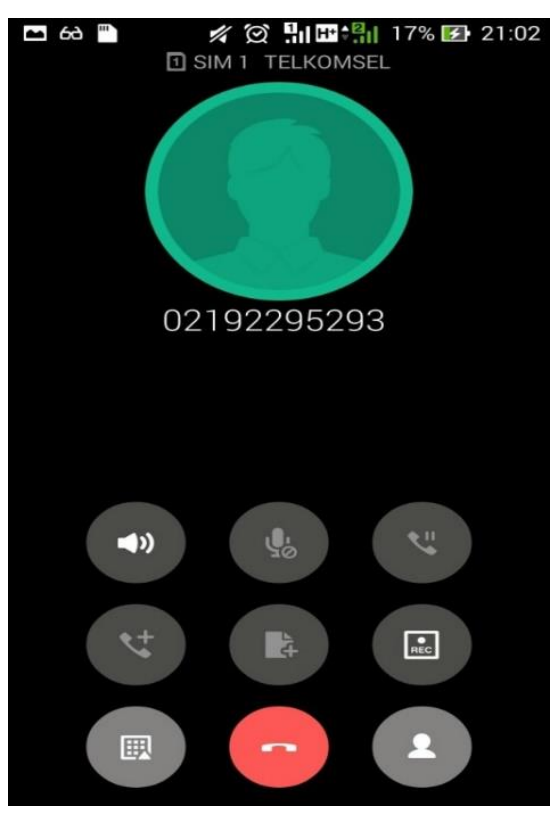

Gambar 16 Halaman panggilan

\subsection{Halaman Help}

Tampilan dibawah ini merupakan tampilan halaman help yang berfungsi untuk menampilkan tata cara penggunaan aplikasi.

\begin{tabular}{|c|}
\hline HELP \\
\hline $\begin{array}{l}\text { 1. Klik Tombol Find Venue untuk } \\
\text { menampilkan daftar lapangan futsal di } \\
\text { Depok. }\end{array}$ \\
\hline $\begin{array}{l}\text { 2. Pilih salah satu Lapangan Futsal } \\
\text { sesuai keinginan anda. }\end{array}$ \\
\hline $\begin{array}{l}\text { 3. Kemudian akan muncul tampilan } \\
\text { informasi lapangan futsal yang sudah } \\
\text { anda pilih. }\end{array}$ \\
\hline $\begin{array}{l}\text { 4. Lalu Tombol CEK LOKASI untuk } \\
\text { navigasi ke lokasi lapangan futsal } \\
\text { yang sudah dipilih. }\end{array}$ \\
\hline $\begin{array}{l}\text { 5. Selanjutnya Tombol CALL untuk } \\
\text { melakukan panggilan ke lapangan } \\
\text { futsal. }\end{array}$ \\
\hline $\begin{array}{l}\text { 6. Jika ingin kembali menu utama } \\
\text { dapat menyentuh tombol kembali } \\
\text { pada smartphone. }\end{array}$ \\
\hline
\end{tabular}

\section{Gambar 17 Halaman Help}

\subsection{Halaman About}

Tampilan di bawah ini merupakan tampilan halaman about yang menjelaskan tentang tujuan pembuatan aplikasi ini. 


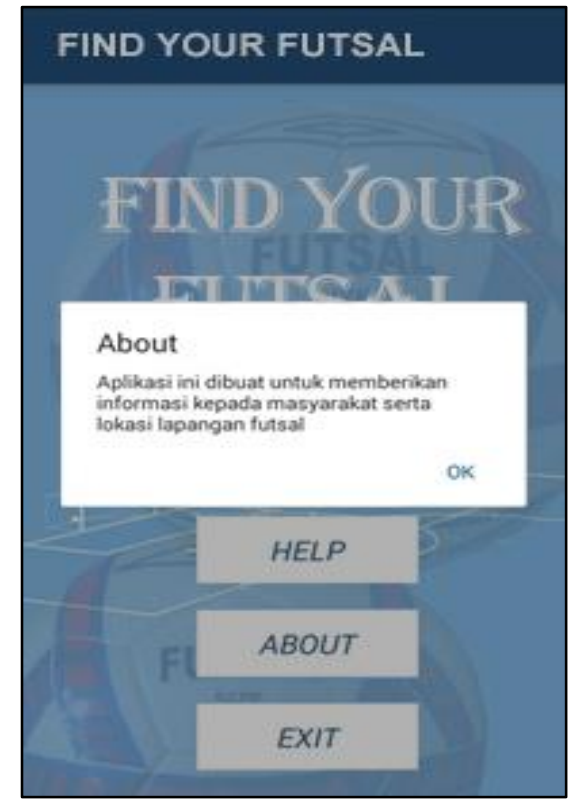

Gambar 18 Halaman About

\subsection{Halaman Exit}

Tampilan dibawah ini merupakan tampilan halaman keluar yang berisi dua pilihan yaitu pilihan untuk keluar dari aplikasi atau tetap berada di dalam aplikasi.

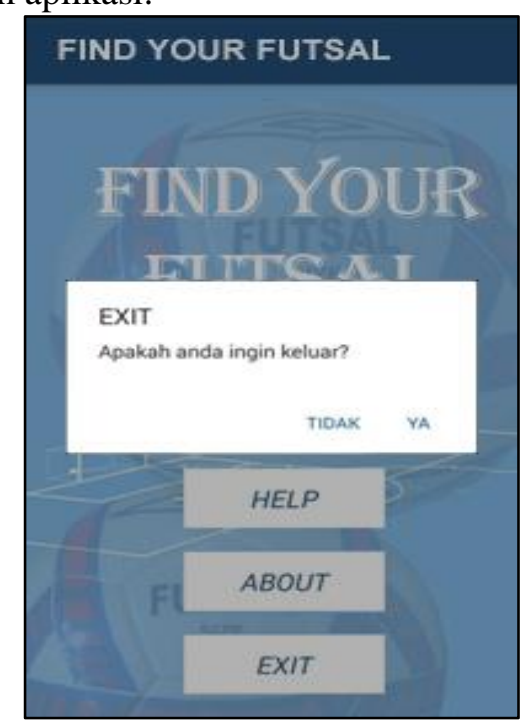

Gambar 19 Halaman Exit

\subsection{Kuisioner}

Untuk kuisioner Peneliti menggunakan skala likert. Kuisioner ini memiliki 5 pertanyaan dan pilihan jawabannya ada 4 yaitu SS (Sangat Setuju), S (Setuju), TS (Tidak Setuju), dan STS (Sangat Tidak Setuju). Jumlah responden ada 20 orang.

Berikut adalah pertanyaan beserta jawaban yang diberikan oleh responden

Tabel 3.2 Kuisioner

\begin{tabular}{|c|c|c|c|c|c|c|}
\hline \multirow[t]{2}{*}{ No } & \multirow[t]{2}{*}{ Pertanyaan } & \multicolumn{4}{|c|}{ Pilihan Jawaban } & \multirow{2}{*}{$\begin{array}{l}\text { SS* } \\
(\%)\end{array}$} \\
\hline & & $\begin{array}{l}\text { SS } \\
\text { (4) }\end{array}$ & $\begin{array}{c}S \\
\text { (3) } \\
\end{array}$ & $\begin{array}{l}\text { TS } \\
\text { (2) }\end{array}$ & \begin{tabular}{|c} 
STS \\
$(1)$ \\
\end{tabular} & \\
\hline 1. & $\begin{array}{l}\text { Apakah } \\
\text { aplikasiFind Your } \\
\text { Futsal ini } \\
\text { menarik? }\end{array}$ & 8 & 10 & 2 & 0 & 82,5 \\
\hline 2. & $\begin{array}{l}\text { Apakah tampilan } \\
\text { aplikasiFind Your } \\
\text { Futsal ini sudah } \\
\text { cukup baik? }\end{array}$ & 5 & 10 & 3 & 2 & 72,5 \\
\hline 3. & $\begin{array}{l}\text { Apakah } \\
\text { aplikasiFind Your } \\
\text { Futsal ini cukup } \\
\text { praktis? }\end{array}$ & 5 & 10 & 4 & 1 & 73,75 \\
\hline 4. & $\begin{array}{l}\text { Apakah aplikasi } \\
\text { ini mudah } \\
\text { dipahami? }\end{array}$ & 4 & 12 & 4 & 0 & 75 \\
\hline 5. & $\begin{array}{l}\text { Apakah tampilan } \\
\text { informasi lapangan } \\
\text { futsal aplikasi ini } \\
\text { sudah cukup baik? }\end{array}$ & 3 & 9 & 8 & 0 & 71,25 \\
\hline 6. & $\begin{array}{l}\text { Apakah informasi } \\
\text { lapangan futsal } \\
\text { aplikasi ini sudah } \\
\text { lengkap dan jelas? }\end{array}$ & 3 & 10 & 4 & 3 & 70,25 \\
\hline 7. & $\begin{array}{l}\text { Apakah informasi } \\
\text { lapangan futsal } \\
\text { yang ditampilkan } \\
\text { mudah } \\
\text { dimengerti? }\end{array}$ & 4 & 8 & 8 & 0 & 70 \\
\hline 8. & $\begin{array}{l}\text { Apakah aplikasi } \\
\text { ini membantu } \\
\text { pengguna dalam } \\
\text { menemukan } \\
\text { lapangan futsal } \\
\text { yang diinginkan? }\end{array}$ & 3 & 9 & 8 & 0 & 71,25 \\
\hline 9. & $\begin{array}{l}\text { Bagaimana dengan } \\
\text { navigasi dan fitur } \\
\text { yang ditawarkan? }\end{array}$ & 4 & 12 & 3 & 1 & 74,75 \\
\hline 10. & $\begin{array}{l}\text { Apakah } \\
\text { AplikasiFind Your } \\
\text { Futsal yang telah } \\
\text { dibuat sesuai } \\
\text { dengan } \\
\text { kebutuhan? } \\
\end{array}$ & 5 & 10 & 4 & 1 & 73,75 \\
\hline
\end{tabular}

Pada tabel 3.2 kolom SS* merupakan perhitungan menggunakan rumus:

Summated Scale $=$ $\frac{\text { (bobot setiap pilihan } \mathrm{x} \sum \text { jawaban) }}{\sum \text { responden } \mathrm{x} \text { bobot maksimal pilihan }} \times 100 \%$

Dari skor setiap butir pertanyaan, kemudian dirata-rata dan dikonversi ke dalam kategori sebagai berikut: 
- $76 \%-100 \%=$ sangat baik/menarik/sesuai/efektif

- $51 \%-75 \%=$ baik/menarik/sesuai/efektif

- $26 \%-50 \%=$ kurang baik/menarik/sesuai/efektif

- $0 \%-25 \%=$ tidak baik/menarik/sesuai/efektif

Diketahui bahwa semua komponen program sudah berfungsi dengan baik, yaitu memperoleh skor $73,5 \%$.

\section{Kesimpulan}

Aplikasi GIS lapangan futsal di wilayah Kota Tangerang berbasis Android telah selesai dibuat dan diterapkan pada smartphone. Kesulitan yang dialami dalam membuat aplikasi ini adalah dalam membuat maps, dibutuhkan ketelitian dalam menghubungkan titik kordinatdengan maps.

Aplikasi ini mempunyai kelebihan selain mencari lapangan futsal yaitu menampilkan secara detail informasi lapangan futsal. Informasi yang di dapat oleh pengguna yaitu alamat, nomor telpon, jumlah lapangan, jenis lapangan, ukuran lapangan, jam operasional dan, harga sewa lapangan. Aplikasi ini dapat melakukan panggilan untuk memesan lapangan futsal via telpon.

Hasil uji coba yang telah diterapkan pada beberapa smartphone android dapat disimpulkan proses aplikasi berjalan baik pada smartphone Samsung Galaxy S7 Edge dengan versi system operasi 7.0, android Asus Zenfone 5 dengan versi sistem operasi 4.4.2, android Samsung Galaxy Grand Duos dengan versi sistem operasi 4.4.2, android Vivo Y555 dengan versi sistem operasi 6.0. Aplikasi ini juga memiliki kekurangan dimana di dalam aplikasi ini user interface hanya mencakup 1 wilayah saja, serta pengembangannya terhadap platform lain seperti IOS.

Aplikasi GIS Lapangan Futsal di Kota Tangerang pada ponsel berbasis Android diharapkan memiliki tampilan user interface yang lebih baik, cakupan wilayah yang lebih luas, dan pengembangan terhadap platform lain.

\section{Referensi}

Achwani, Muhammad. 2016, Peraturan Permainan Futsal 2015/2016 (Draft Terjemahan ke Bahasa Indonesia Untuk Asosiasi Futsal Indonesia), FIFA.

N. Safaat, 2015, "Pemograman Aplikasi Mobile Smartphone Dan Tablet PC Berbasis Android", Bandung, Informatika.

Rena Ariyanti, Khairil, Indra Kanedi, Jurnal Media Infotama Vol. 11 No. 2, September 2015 ISSN 1858 - 2680 Pemanfaatan Google Maps Api
Pada Sistem Informasi Geografis Direktori Perguruan Tinggi Di Kota Bengkulu

M. Ichwan, Fifin Hakiky, Jurnal Informatika No.2, Vol. 2, Mei - Agustus 2011, Pengukuran Kinerja Goodreads Application Programming Interface (Api) Pada Aplikasi Mobile Android (Studi Kasus Untuk Pencarian Data Buku)

Irawan, 2012, "Belajar Interaktif Javascript untuk Orang Awam Edisi ke-2", Maxikom, Palembang

Madcoms, 2009, "Panduan Lengkap : Adobe Photoshop CS4", Jakarta, Andi.

Suyanto, Asep Herman, 2008, “Step by Step Web Design Theory and Practice Edisi II", Yogyakarta., Andi Publisher.

Dhimas, Andreas ," Cara Mudah Merancang Storyboard untuk Animasi Keren”, Taka Publisher, Yogyakarta, 2013 